\title{
IMPLEMENTASI PRINSIP SUBROGASI PADA ASURANSI KENDARAAN BERMOTOR: STUDI PADA PT PAN PACIFIC INSURANCE
}

\author{
Suhaila Zulkifli ${ }^{1}$, Luthvia Meidina ${ }^{2 *}$, Shalihin Hernata Dhalimunthe ${ }^{2}$, \\ Intan Carolyn Ginting ${ }^{2}$ \\ ${ }^{1}$ Dosen Fakultas Hukum, Universitas Prima Indonesia, Medan \\ ${ }^{2}$ Mahasiswa Fakultas Hukum, Universitas Prima Indonesia, Medan \\ *Penulis Korespondensi: Luthvia Meidina \\ Email Korespondensi: luthviameidina07@gmail.com
}

Tanggal Penyerahan: 27 Juni 2020

Tanggal Publikasi: 10 Juli 2020

\begin{abstract}
Abstrak. Penelitian ini bertujuan untuk mendeskripsikan ketentuan implementasi Prinsip Subrogasi di dalam Perjanjian Asuransi Kendaraan Bermotor; hal-hal yang menjadi hambatan pihak tertanggung dalam pengajuan klaim; serta tanggungjawab PT Pan Pacific Insurance mengenai prinsip subrogasi atas kerugian yang disebabkan oleh keterlibatan pihak ketiga. Untuk mencapai tujuan tersebut, penelitian ini menggunakan pendekatan yuridisnormatif yang dilaksanakan dengan berdasar pada tinjauan bahan pustaka atau data sekunder. Selain itu, penelitian ini juga dipertajam dengan metode penelitian studi empiris yang biasa pula disebut dengan penelitian hukum sosiologis. Adapun jenis penelitian ini adalah deskriptif analisis, dengan jenis data yang terdiri dari 2 (dua), yakni data primer dan data sekunder. Sedangkan teknik analisis data yang digunakan dalam penelitian ini adalah teknik analisis data kualitatif. Hasil penelitian menunjukan bahwa PT Pan Pacific Insurance sama halnya dengan perusahaan asuransi pada umumnya dalam pengaplikasian asuransi, dimana menawarkan prinsip subrogasi sebagai salah satu dasar dalam pengaplikasian asuransi. Dalam pelaksanaannya, terdapat berbagai hambatan yang berasal dari perusahaan asuransi sendiri maupun pihak tertanggung. Tanggung jawab perusahaan asuransi atas klaim ganti rugi, sesuai dengan nilai limit nominal pertanggung. Dengan demikian, maka sisa kekurangan dari biaya perbaikan terhadap objek asuransi ditanggung oleh pihak ketiga sesuai dengan kesepakatannya bersama pihak tertanggung.
\end{abstract}

Kata Kunci:

Asuransi;

Kendaraan Bermotor;

Limit Nominal Pertanggung; Prinsip Subrogasi.

artikel dengan akses terbuka dibawah lisensi CC BY -4.0

\section{PENDAHULUAN}

Kecerobohan manusia bisa menjadi salah satu faktor utama terjadinya kecelakaan. Apalagi produksi kendaraan bermotor yang semakin meningkat karena tingginya minat konsumen dari tahun ke tahun, yang kemudian berdampak dalam aspek ekonomi. Dari situasi inilah perusahaan asuransi mengambil peran sekaligus peluang terhadap konsumen, dimana akan menanggung kerugian yang disebut sebagai resiko.

DOI: https://doi.org/10.37276/sjh.v2i1.65 
Adapun ciri-ciri terkait resiko yang berhubungan dengan asuransi, yaitu: ${ }^{1}$

a. Ancaman atas objek asuransi;

b. Musibah yang diakibatkan dari faktor alam, ekonomi, dan manusia;

c. Diidentifikasi sebagai resiko pribadi, kekayaan dan tanggung jawab; dan

d. Berpeluang menyebabkan kerugian.

Lebih lanjut, aktifitas asuransi atau dikenal dengan istilah perasuransian diartikan sebagai pertanggungan ataupun perlindungan terhadap suatu objek dari ancaman risiko yang berefek kerugian. ${ }^{2}$ Berdasarkan Pasal 1 Undang-Undang Republik Indonesia Nomor 40 Tahun 2014 tentang Perasuransian (selanjutnya disebut UU No. 40 Tahun 2014), mengartikan bahwa "Asuransi adalah perjanjian antara dua pihak, yaitu perusahaan asuransi dan pemegang polis, yang menjadi dasar bagi penerimaan premi oleh perusahaan asuransi sebagai imbalan untuk:

a. memberikan penggantian kepada tertanggung atau pemegang polis karena kerugian, kerusakan, biaya yang timbul, kehilangan keuntungan, atau tanggung jawab hukum kepada pihak ketiga yang mungkin diderita tertanggung atau pemegang polis karena terjadinya suatu peristiwa yang tidak pasti; atau

b. memberikan pembayaran yang didasarkan pada meninggalnya tertanggung atau pembayaran yang didasarkan pada hidupnya tertanggung dengan manfaat yang besarnya telah ditetapkan dan/atau didasarkan pada hasil pengelolaan dana."

Oleh karena itu, perjanjian asuransi adalah perjanjian bersama antara perusahaan asuransi dan tertanggung, dimana salah satu bentuk dari Perasuransian ialah asuransi kendaraan bermotor. Dilain sisi, hal umum yang dimuat dalam perjanjian asuransi ialah klausul bahwa perusahaan asuransi mengikatkan dirinya kepada tertanggung berdasarkan objek asuransi. Apabila terjadi insiden sehingga menimbulkan kerugian atas objek asuransi, maka tertanggung akan mengajukan klaim. Klaim adalah pengajuan pembayaran dari tertanggung sehingga menerima sejumlah uang atau premi dari perusahaan asuransi. Klaim adalah hak yang diperoleh tertanggung berdasarkan statusnya sebagai konsumen dari perusahaan asuransi. ${ }^{3}$ Selama jangka waktu pertanggungan terkait perjanjian asuransi, maka perusahaan asuransi berkewajiban memberikan kompensasi kepada tertanggung sesuai dengan syarat dan ketentuan yang berlaku untuk kondisi polis. Namun dari beberapa kondisi, pengajuan klaim tidak selamanya berjalan dengan baik. Terdapat berbagai faktor-faktor penghambat, dan salah satu faktor tersebut ialah terkait klausul ganti rugi tertentu yang tidak dicantumkan di dalam polis. ${ }^{4}$

\footnotetext{
${ }^{1}$ Selvi Harvia Santri. (2018). Prinsip Subrogasi pada Asuransi Kendaraan Bermotor menurut Kitab Undang-Undang Hukum Dagang. UIR Law Review, Universitas Islam Riau, 2(2), hlm. 354.

${ }^{2}$ Abdulkadir Muhammad. (2002). Hukum Asuransi Indonesia. Bandung: PT. Citra Aditya Bakti, hlm. 5.

${ }^{3}$ Ade Hari Siswanto \& Nanik Sri Handayani. (2009). Penyelesaian Klaim pada Asuransi Kendaraan Bermotor melalui Badan Mediasi Asuransi. Lex Jurnalica, Universitas Esa Unggul, 6(3), hlm. 140 - 141.

${ }^{4}$ Novianta Budi Surana. (2016). Kajian Yuridis Perlindungan Hukum Tertanggung pada Perjanjian Asuransi Kendaraan Bermotor di PT. Asuransi Ramayana Tbk. Jakarta. Jurnal Idea Hukum, Universitas Jenderal Soedirman, 2(1), hlm. 31.
} 
Dari uraian di atas, apabila tertanggung melaporkan terjadi evenemen kecelakaan, perusahaan asuransi akan membentuk tim investigasi dengan tujuan untuk memastikan laporan yang diajukan tertanggung dan melihat langsung keadaan di lapangan. ${ }^{5}$ Penyelidikan lapangan yang dilakukan oleh perusahaan asuransi sebagaimana pada Pasal 9 Surat Keputusan Asosiasi Asuransi Umum Indonesia Nomor 06/AAUI/2007 tentang Polis Standar Asuransi Kendaraan Bermotor Indonesia, mengatur bahwa "Penanggung berhak melakukan pemeriksaan atas Kendaraan Bermotor setiap saat selama jangka waktu pertanggungan".

Adapun dalam pengaplikasian asuransi, terdapat prinsip-prinsip dasar yang harus dipahami dan dipatuhi oleh tertanggung dan penanggung untuk mengatur hak-hak tertanggung yang wajib dipenuhi penanggung atau perusahaan asuransi sehingga sebuah perjanjian asuransi dapat dinyatakan sah. Salah satu prinsip dasar tersebut adalah prinsip subrogasi. Subrogasi merupakan pendukung prinsip indemnity. Subrogasi berperan agar pihak tertanggung tidak mendapatkan recovery lebih dari kerugian yang dideritanya, atau sering disebut sebagai corollary on indemnity. ${ }^{6}$ Recovery lebih ialah apabila perusahaan asuransi telah membayarkan kerugian pihak tertanggung, dengan begitu pihak tertanggung tidak berhak mendapatkan ganti rugi lagi dari pihak ketiga. Misalnya, apabila terjadi insiden yang melibatkan/diakibatkan oleh pihak ketiga, maka tertanggung tetap dapat mengajukan klaim kepada perusahaan asuransi, namun nominal dari ganti rugi tersebut didapatkan dari kompensasi yang dibayarkan oleh pihak ketiga kepada perusahaan asuransi. ${ }^{7}$

Pihak ketiga selaku penyebab timbulnya kerugian atas objek asuransi tetap harus bertanggung jawab, walaupun kendaraan tersebut telah diasuransikan. Hal ini sebagaimana pada Pasal 1365 Staatsblad Nomor 23 Tahun 1847 tentang Burgerlijk Wetboek voor Indonesie (BW)/Kitab Undang-Undang Hukum Perdata (selanjutnya disebut KUHPerdata), mengatur bahwa:

"Tiap perbuatan melanggar hukum, yang membawa kerugian kepada orang lain, mewajibkan orang yang karena salahnya menerbitkan kerugian itu, mengganti kerugian tersebut."

Berdasarkan pemaparan ketentuan di atas, pihak ketiga wajib mengganti kerugian atas kesalahannya tersebut. Ketentuan pasal ini dapat dianggap sebagai pelindung bagi perusahaan asuransi, karena perusahaan tidak perlu mengganti apa yang telah dilimpahkan kepadanya. Meskipun pada awalnya perusahaan tetap wajib dengan itikad baik mengganti kerugian yang dialami dengan berpegang teguh pada perjanjian asuransi dan ketentuan prinsip yang ada.

\footnotetext{
${ }^{5}$ Erlina B. (2010). Klaim Ganti Rugi dalam Perjanjian Asuransi Kendaraan Bermotor. Pranata Hukum, Universitas Bandar Lampung, 5(2), hlm. 108.

${ }^{6}$ Kun Wahyu Wardana. (2009). Hukum Asuransi: Proteksi Kecelakaan Transportasi. Bandung: CV. Mandar Maju, hlm. 42.

${ }^{7}$ Ni Putu Eni Sulistyawati \& I Ketut Sudantra. (2017). Perlindungan Hukum Bagi Pihak Ketiga dalam Perjanjian Asuransi Kendaraan Bermotor Rent A Car di Kota Denpasar (Studi Kasus pada PT. Asuransi Wahana Tata dan PT. Asuransi Astra Buana). Kertha Semaya: Journal Ilmu Hukum, Universitas Udayana, 5(1), hlm. 2 .
} 
Berdasarkan uraian diatas, maka penelitian ini bertujuan untuk memahami beberapa hal terkait keberadaan PT Pan Pacific Insurance selaku perusahaan asuransi, yaitu:

1. Bagaimanakah ketentuan implementasi Prinsip Subrogasi di dalam Perjanjian Asuransi Kendaraan Bermotor di PT Pan Pacific Insurance?

2. Apa saja hal-hal yang menjadi hambatan pihak tertanggung dalam pengajuan klaim di PT Pan Pacific Insurance?

3. Bagaimanakah tanggungjawab PT Pan Pacific Insurance mengenai prinsip subrogasi atas kerugian yang disebabkan oleh keterlibatan pihak ketiga?

\section{METODE}

Penelitian ini menggunakan pendekatan yuridis-normatif. Menurut Soerjono Soekanto pendekatan yuridis normatif merupakan penelitian hukum yang dilaksanakan dengan berdasarkan pada tinjauan bahan pustaka atau data sekunder. Bahan pustaka atau data sekunder menjadi bahan dasar untuk dijadikan objek penelitian berdasarkan penelaahan atas peraturan-peraturan di dalamnya. Lebih lanjut, Bahan pustaka atau data sekunder tersebut dianalisis lebih jauh dengan melakukan perbandingan menggunakan literatur-literatur yang berhubungan dengan objek penelitian tersebut. ${ }^{8}$ Selain itu, Penelitian ini juga dipertajam dengan metode penelitian studi empiris yang biasa pula disebut dengan penelitian hukum sosiologis, untuk melihat penerapan hukum terhadap peristiwa yang menimbulkan asas subrogasi serta pelaksanaannya dalam perjanjian asuransi. ${ }^{9}$

Jenis penelitian ini adalah deskriptif analisis, yakni membahas proses yang menyebabkan timbulnya asas subrogasi dan penerapannya dalam perjanjian asuransi. Adapun jenis data dalam penelitian ini terdiri dari 2 (dua), yakni data primer dan data sekunder. Data primer diperoleh langsung oleh peneliti dari informan melalui proses wawancara. ${ }^{10}$ Dalam penelitian ini, data primer tersebut diperoleh dari hasil wawancara bersama Bapak Gilang selaku Kepala Cabang Medan PT Pan Pacific Insurance serta Bapak Hepiyaman selaku Bagian Klaim. Sedangkan data sekunder, diperoleh dari sumber-sumber yang telah tersedia. ${ }^{11}$ Dalam penelitian ini, data sekunder tersebut menggunakan 2 (dua) jenis bahan, yakni:

a. Bahan Hukum Primer yang bersifat otoritatif, berupa peraturan perundangundangan, ${ }^{12}$ antara lain:

1) Kitab Undang-Undang Hukum Perdata;

2) Kitab Undang-Undang Hukum Dagang;

3) Undang-Undang Nomor 40 Tahun 2014 tentang Perasuransian.

\footnotetext{
${ }^{8}$ Soerjono Soekanto \& Sri Mamudji. (2001). Penelitian Hukum Normatif: Suatu Tinjauan Singkat. Jakarta: PT. Raja Grafindo Persada, hlm. 13 - 14.

${ }^{9}$ La Ode Husen, et al. (2020). Pengamanan Intelijen Kepolisian Terhadap Putusan Pengadilan Atas Objek Sengketa. SIGn Jurnal Hukum, CV. Social Politic Genius (SIGn), 1(2), hlm. 138.

${ }^{10}$ M. Iqbal Hasan. (2002). Pokok-Pokok Materi Metodologi Penelitian dan Aplikasinya. Bogor: Ghalia Indonesia, hlm. 82 .

${ }^{11}$ Ibid.

${ }^{12}$ Peter Mahmud Marzuki. (2006). Penelitian Hukum. Jakarta: Kencana Prenada Media Group, hlm. 141.
} 
b. Bahan hukum sekunder yang berupa doktrin atau teori-teori dan berasal dari literatur hukum, atau dapat juga berasal dari hasil penelitian, maupun artikel ilmiah.

Teknik analisis data yang digunakan dalam penelitian ini adalah teknik analisis data kualitatif, melalui pemaparan dan penjabaran data yang diperoleh dalam bentuk kalimat atau uraian dengan penyesuaian atas pokok bahasan, tujuan, konsep yang berhubungan secara sistematis, kemudian disimpulkan sebagai hasil akhir dalam penelitian ini. ${ }^{13}$

\section{HASIL DAN PEMBAHASAN}

\section{A. Ketentuan Implementasi Prinsip Subrogasi dalam Perjanjian Asuransi Kendaraan Bermotor di PT Pan Pacific}

PT Pan Pacific Insurance terbentuk dengan nama PT Asuransi Jaya Inti pada tanggal 27 Februari 1997. Perusahaan asuransi merupakan perusahaan asuransi lokal yang memiliki produk-produk asuransi umum dan lengkap sehingga mampu bersaing dengan perusahaan asuransi lain dimana setiap tahunnya mengalami pertumbuhan. Dengan portfolio produk yang lengkap dan sumber daya manusia yang berkualitas tinggi, PT Pan Pacific Insurance berhasil menjadi salah satu perusahaan asuransi umum yang berkembang dengan cepat dan mendapatkan kepercayaan, terhitung dalam waktu sepuluh tahun terakhir.

Pertanggungan yang dijamin dalam perjanjian asuransi kendaraan bermotor pada PT Pan Pacific Insurance adalah kerusakan yang terjadi secara langsung yang disebabkan oleh benturan, tabrakan, tergelincir, terbalik, tindak kejahatan, pencurian dan TJH (tanggung jawab hukum) pihak ketiga. Dalam pelaksanaannya, PT Pan Pacific Insurance sama halnya dengan perusahaan asuransi pada umumnya, dimana tunduk pada hukum yang berlaku. PT Pan Pacific Insurance juga menerapkan prinsip subrogasi pada pelaksanaan asuransi kendaraan bermotor kepada setiap nasabahnya. Kerugian yang dialami pihak tertanggung akibat peristiwa yang terjadi, kemudian dilihat dari sisi kerugian yang muncul. Sedangkan apabila pihak ketiga yang atas kelalaiannya mengakibatkan terjadinya kerugian terhadap objek asuransi, maka di situlah muncul hak subrogasi. ${ }^{14}$

Hak subrogasi merupakan salah satu prinsip asuransi yang dimana berdasarkan Pasal 284 Staatsblad Nomor 23 Tahun 1847 tentang Wetboek van Koophandel voor Indonesie/Kitab Undang-Undang Hukum Dagang (selanjutnya disebut KUHD), mengatur bahwa:

"Penanggung yang telah membayar kerugian barang yang dipertanggungkan, memperoleh semua hak yang sekiranya dimiliki oleh tertanggung terhadap pihak ketiga berkenaan dengan kerugian itu; dan

\footnotetext{
${ }^{13}$ Abdulkadir Muhammad. (2004). Hukum dan Penelitian Hukum. Bandung: PT. Citra Aditya Bakti,
} hlm. 127.

${ }^{14}$ Ridwan Khairandy. (2006). Pengantar Hukum Dagang. Yogyakarta: UII Press, hlm. 205. 
tertanggung bertanggung jawab untuk setiap perbuatan yang mungkin merugikan hak penanggung terhadap pihak ketiga itu."

Berdasarkan pemaparan ketentuan di atas, dijelaskan bahwa apabila pihak tertanggung sudah menerima penggantian atas dasar prinsip indemnity, maka pihak tertanggung tidak dibenarkan untuk mendapatkan penggantian dari pihak ketiga. ${ }^{15}$ Apabila kerugian pihak tertanggung disebabkan oleh pihak ketiga, oleh karenanya pihak tertanggung mempunyai pilihan menuntut penggantian kepada pihak ketiga atau kepada pihak penanggung sesuai dengan perjanjian asuransi.

Berikut ini adalah proses pengajuan klaim pada saat kendaraan tertanggung mengalami kecelakaan:

1. Tertanggung memberitahukan kepada perusahaan asuransi bahwa telah terjadi kecelakaan dengan mengajukan klaim dan melibatkan pihak ketiga;

2. Tertanggung dan pihak ketiga diwajibkan untuk melengkapi data-data yang diminta oleh perusahaan asuransi sebagai data pendukung dalam pengajuan klaim yang didalamnya menyertakan SIM, KTP, STNK, kartu anggota PT Pan Pacific Insurance tertanggung, serta surat pernyataan damai untuk tanggung jawab pihak ketiga;

3. Apabila data pendukung sudah dinyatakan lengkap, perusahaan asuransi melakukan survey dengan melihat kondisi kendaraan. Selanjutnya perusahaan asuransi melakukan "foto gandeng" sebagai bukti adanya kerusakan pada objek asuransi;

4. Perusahaan asuransi akan memberikan Surat Perintah Kerja (SPK) kepada pihak tertanggung untuk kemudian diajukan kepada bengkel rekanan perusahaan asuransi.

Berdasarkan proses pengajuan klaim di atas, dapat dilihat betapa pentingnya pemahaman bersama antara tertanggung dan perusahaan asuransi. Hal tersebut menjadi syarat untuk melakukan klaim ganti rugi atas kerugian yang ditimbulkan oleh objek asuransi. Lebih lanjut dalam proses pengajuan klaim, perusahaan asuransi juga mempunyai batas waktu yang ditentukan. Khusus PT Pan Pacific Insurance sendiri, memiliki tenggang waktu $5 \times 24$ jam setelah terjadinya kecelakaan. Berdasarkan ketentuan tersebut, apabila pihak tertanggung terlambat mengajukan klaim kepada perusahaan asuransi, maka perusahaan asuransi bisa saja menolak klaim asuransi yang diajukan oleh pihak tertanggung.

\section{B. Hal-hal yang Menjadi Hambatan Pihak Tertanggung Dalam Proses Pengajuan Klaim Subrogasi di PT Pan Pacific Insurance}

Asuransi kendaraan berperan sebagai pengalihan resiko kerugian finansial akibat kerusakan kendaraan bermotor. Namun, kondisi real atau kenyataan di lapangan menunjukkan bahwa tidak semua klaim ganti rugi akan diterima oleh perusahaan

${ }^{15}$ Abdul R. Saliman. (2004). Hukum Bisnis untuk Perusahaan: Teori dan Contoh Kasus. Jakarta: Kencana Prenada Media Group, hlm. 186. 
asuransi. Perusahaan asuransi kendaraan bermotor memiliki wewenang untuk menolak klaim perbaikan kendaraan yang diajukan pihak tertanggung kepada mereka. Meskipun demikian, keputusan untuk menolak tersebut tidak dapat dilakukan secara sepihak, karena ada dasar aturan dan harus melalui beberapa tahapan proses, seperti yang sudah dipaparkan sebelumnya.

Ketika tertanggung mengajukan klaim kepada perusahaan asuransi, maka terdapat syarat untuk melengkapi data pendukung sebagai bagian dari pengajuan klaim. Data pendukung dari pihak tertanggung dan pihak ketiga, diwajibkan dalam keadaan masih aktif. Apabila salah satu data pendukung dari pihak tertanggung maupun pihak ketiga sudah tidak aktif (seperti KTP, SIM, STNK), maka pengajuan klaim oleh pihak tertanggung tidak dapat diterima oleh perusahaan asuransi sesuai dengan peraturan perundang-undangan yang berlaku.

Pada sisi lain, hasil wawancara penulis dengan Bapak Gilang ${ }^{16}$ yang kemudian diafirmasi pula oleh hasil wawancara dengan Bapak Hepiyaman ${ }^{17}$, juga ditemukan bahwa yang menjadi hambatan dalam pengajuan klaim, salah satunya adalah perihal aktifitas survey di lapangan. Misalnya, pihak tertanggung PT Pan Pacific Insurance sudah kooperatif untuk mengikuti prosedur dalam aktifitas survey yang dilakukan oleh perusahaan asuransi, akan tetapi pihak ketiga tidak dapat hadir karena adanya halangan, begitu pula sebaliknya. Kondisi demikian merupakan hambatan yang lazim dijumpai di lapangan.

Setiap tertanggung juga harus mempunyai moral hazard yang baik, dimana hal tersebut berhubungan dengan karakter ataupun sifat dari pihak tertanggung. Moral hazard menjadi penting karena pada beberapa kondisi dimana pihak tertanggung mengalami kerugian atas objek asuransi, perusahaan asuransi sering kali menemukan ketidakjelasan informasi atas kronologi kejadian secara terperinci. Pada situasi tersebut, terdapat kesan bahwa pihak tertanggung menutup-nutupi fakta di lapangan, sehingga menghambat perusahaan asuransi dalam menerapkan prinsip subrogasi. Misalnya, pihak tertanggung hanya menjelaskan sebagian kejadian yang menyebabkan kerugian terhadap objek asuransi, sementara informasi terkait peran pihak ketiga yang menyebabkan kerugian tersebut, sangat jarang dilaporkan. ${ }^{18} \mathrm{Hal}$ tersebut menjadi hambatan bagi pihak tertanggung untuk membuktikan keterlibatan pihak ketiga.

Hambatan lainnya lagi ialah kondisi yang dikenal dengan istilah Tanggung Jawab Hukum terhadap Pihak Ketiga (TJH III), dimana penggantian kerugian yang ditimbulkan atas objek asuransi bukan merupakan tanggung jawab langsung bagi pihak ketiga. Lebih lanjut, dalam TJH III dikenal pula istilah limit nominal pertanggung, yang berarti bahwa apabila nilai kerugian yang ditimbulkan

${ }^{16}$ Wawancara dengan Kepala Cabang PT Pan Pacific Insurance, Medan. Gilang. Tanggal 29 Oktober 2019.

${ }^{17}$ Wawancara dengan Staf Bagian Klaim PT Pan Pacific Insurance, Medan. Hepiyaman. Tanggal 29 Oktober 2019.

${ }^{18}$ Wawancara dengan Kepala Cabang PT Pan Pacific Insurance, Medan. Gilang. Tanggal 29 Oktober 2019. 
dari keterlibatan pihak ketiga atas objek asuransi melampaui nilai dari yang dipertanggungkan, maka pihak tertanggung harus membayar sisanya.

Walaupun sudah diatur di dalam perundang-undangan terkait hak subrogasi, kenyataannya pihak tertanggung masih sering menghadapi hambatan untuk mendapatkan haknya dari perusahaan asuransi.

\section{Tanggung Jawab PT Pan Pacific Insurance terhadap Kerugian yang Ditimbulkan Pihak Ketiga}

Dalam pelaksanaan asuransi, tidak dapat dipungkiri adanya kerugian yang diderita pihak tertanggung, dimana hal tersebut melibatkan pihak ketiga. Dengan demikian, kerugian yang muncul akibat pihak ketiga, secara otomatis memposisikan pihak ketiga sebagai penanggung jawab atas kerugian tersebut sebagaimana telah dipaparkan pada ketentuan Pasal 1365 KUHPerdata sebelumnya. Namun, kondisi tersebut tidak memposisikan hubungan pertanggungjawaban langsung antara pihak ketiga dengan pihak tertanggung, melainkan hubungan pertanggungjawaban langsung antara pihak ketiga dengan perusahaan asuransi. ${ }^{19}$ Meskipun demikian, pihak tertanggung tidak diperbolehkan untuk mendapat nilai ganti rugi lebih dari kerugian yang dialaminya, jika perusahaan asuransi sudah mengganti kerugian atas objek asuransi pihak tertanggung.

Sehubungan dengan tanggung jawab perusahaan asuransi sebagaimana penjelasan sebelumnya, telah diuraikan mengenai TJH III dimana terdapat limit nominal pertanggung. Dengan demikian, perusahaan asuransi hanya akan mengganti nilai kerugian sesuai klausul yang tercantum dalam polis asuransi berdasarkan kesepakatan tersebut, sehingga tanggung jawab perusahaan asuransi hanya berlaku sesuai dengan nilai limit $\mathrm{TJH}$ tersebut. ${ }^{20}$ Misalnya, mobil tertanggung ditabrak oleh mobil pihak ketiga. Selanjutnya pihak tertanggung menghubungi perusahaan asuransi bahwa terjadi kecelakaan yang mengakibatkan kerugian pada mobil miliknya. Sesuai prosedur, setelah kedua belah pihak melengkapi data pendukung, perusahaan asuransi melakukan survey terhadap mobil sebagai objek asuransi. Setelah dilakukan survey oleh perusahaan asuransi, ditemukan kerusakan pada mobil tertanggung dengan nilai yang melebihi limit TJH sebagaimana klausul dalam polis asuransi tertanggung. Adapun limit TJH yang dipertanggungkan pada mobil sebagai objek asuransi adalah senilai Rp. 10.000.000,00, sedangkan kerugian yang ditimbulkan akibat keterlibatan pihak ketiga melebihi limit TJH. ${ }^{21}$ Dengan demikian, maka sisa kekurangan dari biaya perbaikan mobil ditanggung oleh pihak ketiga sesuai dengan kesepakatannya bersama pihak tertanggung.

\footnotetext{
${ }^{19}$ Man Suparman Sastrawidjaja. (2003). Aspek-Aspek Hukum Asuransi dan Surat Berharga. Bandung: PT. Alumni, hlm. 74.

${ }^{20}$ Wawancara dengan Kepala Cabang PT Pan Pacific Insurance, Medan. Gilang. Tanggal 29 Oktober 2019.

${ }^{21}$ Wawancara dengan Staf Bagian Klaim PT Pan Pacific Insurance, Medan. Hepiyaman. Tanggal 29 Oktober 2019.
} 


\section{KESIMPULAN DAN SARAN}

PT Pan Pacific Insurance sama halnya dengan perusahaan asuransi pada umumnya dalam pengaplikasian asuransi, dimana menawarkan prinsip subrogasi sebagai salah satu dasar dalam pengaplikasian asuransi. Tentu saja dalam pelaksanaannya terdapat berbagai hambatan yang berasal dari perusahaan asuransi sendiri maupun pihak tertanggung. Dalam polis asuransi dikenal TJH III yang menjelaskan limit nominal pertanggung sesuai dengan klausul di dalam polis asuransi. Dalam pengajuan klaim subrogasi, perusahaan asuransi hanya bertanggung jawab atas klaim ganti rugi sesuai dengan nilai limit nominal pertanggung. Dengan demikian, maka sisa kekurangan dari biaya perbaikan terhadap objek asuransi ditanggung oleh pihak ketiga sesuai dengan kesepakatannya bersama pihak tertanggung.

\section{REFERENSI}

Abdul R. Saliman. (2004). Hukum Bisnis untuk Perusahaan: Teori dan Contoh Kasus. Jakarta: Kencana Prenada Media Group.

Abdulkadir Muhammad. (2002). Hukum Asuransi Indonesia. Bandung: PT. Citra Aditya Bakti.

Abdulkadir Muhammad. (2004). Hukum dan Penelitian Hukum. Bandung: PT. Citra Aditya Bakti.

Ade Hari Siswanto \& Nanik Sri Handayani. (2009). Penyelesaian Klaim pada Asuransi Kendaraan Bermotor melalui Badan Mediasi Asuransi. Lex Jurnalica, Universitas Esa Unggul, 6(3), hlm. 134 - 156.

Erlina B. (2010). Klaim Ganti Rugi dalam Perjanjian Asuransi Kendaraan Bermotor. Pranata Hukum, Universitas Bandar Lampung, 5(2), hlm. 99 - 112.

Kun Wahyu Wardana. (2009). Hukum Asuransi: Proteksi Kecelakaan Transportasi. Bandung: CV. Mandar Maju.

La Ode Husen, et al. (2020). Pengamanan Intelijen Kepolisian Terhadap Putusan Pengadilan Atas Objek Sengketa. SIGn Jurnal Hukum, CV. Social Politic Genius (SIGn), 1(2), hlm. 136 - 148. doi: https://doi.org/10.37276/sjh.v1i2.62

M. Iqbal Hasan. (2002). Pokok-Pokok Materi Metodologi Penelitian dan Aplikasinya. Bogor: Ghalia Indonesia.

Man Suparman Sastrawidjaja. (2003). Aspek-Aspek Hukum Asuransi dan Surat Berharga. Bandung: PT. Alumni.

Ni Putu Eni Sulistyawati \& I Ketut Sudantra. (2017). Perlindungan Hukum Bagi Pihak Ketiga dalam Perjanjian Asuransi Kendaraan Bermotor Rent A Car di Kota Denpasar (Studi Kasus pada PT. Asuransi Wahana Tata dan PT. Asuransi Astra Buana). Kertha Semaya: Journal Ilmu Hukum, Universitas Udayana, 5(1), hlm. 1 - 5.

Novianta Budi Surana. (2016). Kajian Yuridis Perlindungan Hukum Tertanggung pada Perjanjian Asuransi Kendaraan Bermotor di PT. Asuransi Ramayana Tbk. Jakarta. Jurnal Idea Hukum, Universitas Jenderal Soedirman, 2(1), hlm. 29 - 39. doi: http:// dx.doi.org/10.20884/1.jih.2016.2.1.27 
Peter Mahmud Marzuki. (2006). Penelitian Hukum. Jakarta: Kencana Prenada Media Group.

Ridwan Khairandy. (2006). Pengantar Hukum Dagang. Yogyakarta: UII Press.

Selvi Harvia Santri. (2018). Prinsip Subrogasi pada Asuransi Kendaraan Bermotor menurut Kitab Undang-Undang Hukum Dagang. UIR Law Review, Universitas Islam Riau, 2(2), hlm. 354 - 369. doi: https://doi.org/10.25299/uirlrev.2018. vol2(02).2073

Soerjono Soekanto \& Sri Mamudji. (2001). Penelitian Hukum Normatif: Suatu Tinjauan Singkat. Jakarta: PT. Raja Grafindo Persada.

Staatsblad Nomor 23 Tahun 1847 tentang Burgerlijk Wetboek voor Indonesie (BW)/ Kitab Undang-Undang Hukum Perdata.

Staatsblad Nomor 23 Tahun 1847 tentang Wetboek van Koophandel voor Indonesie/ Kitab Undang-Undang Hukum Dagang.

Surat Keputusan Asosiasi Asuransi Umum Indonesia Nomor 06/AAUI/2007 tentang Polis Standar Asuransi Kendaraan Bermotor Indonesia.

Undang-Undang Republik Indonesia Nomor 40 Tahun 2014 tentang Perasuransian. (Lembaran Negara Republik Indonesia Tahun 2014 Nomor 337. Tambahan Lembaran Negara Republik Indonesia Nomor 5618).

I Suhaila Zulkifli, etal.(2020).Implementasi Prinsip Subrogasi pada Asuransi Kendaraan I

Bermotor: Studi pada PT Pan Pacific Insurance. SIGn Jurnal Hukum, CV. Social Politic

I Genius (SIGn), 2(1), hlm. 20-29. doi: https://doi.org/10.37276/sjh.v2i1.65

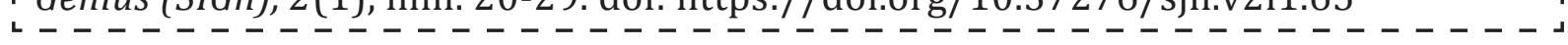

